\title{
SAVE THE BACON! PRIMARY SOURCES FROM FIELDWORK
}

\author{
JAN VANSINA \\ UNIVERSITY OF WISCONSIN-MADISON
}

If very long titles were still acceptable, the one for this note would read SAVE THE EVIDENCE: A PLEA FOR FIELDWORKERS TO MAKE THE RAW MATERIALS OR PRIMARY EVIDENCE FROM THEIR FIELD WORK ACCESSIBLE TO ALL SCHOLARSESPECIALLY ALL RECORDED ORAL DATA.

Ever since ethnographic monographs based on fieldwork were first published, they have raised problems of credibility. In the absence of any evidence at all to test the assertions made, readers of such works have been asked to trust the scholarly authority and integrity of their writers blindly, a stance diametrically contrary to basic tenets in all sciences. It may well be that, at the outset, early practitioners of the craft believed that their observations did not differ in any way from those made by natural scientists in the field-that they needed no evidence because their observations were wholly replicable. Anyone who cared to carry out the experiment-that is, to go to observe the same people in the same field-would find exactly the same situation as described in the monograph. For this was the age of the ethnographic present. Humans were divided into races and tribes, and, just like so many species of songbirds, every human tribe had its own invariant characteristics. A people-watcher need only to enumerate them.

Of course such views were wholly mistaken, but even anthropologists took a long time to become fully aware of both the transient character of their observations and the fallibility of observers. This explains why restudies such as that of Marcel Griaule's ethnographies about the Dogon people of Mali became such causes célebres in the 1980s and 1990s. ${ }^{1}$ Such experi-

${ }^{1}$ While the reappraisal of Margaret Mead by Derek Freeman about Mead's work in Samoa started the furore, Africanists tend to refer to Walter Van Beek, "Dogon Restud- 
ences have strongly confirmed that one needs at least access to the original raw notes in order to assess any monograph based on fieldwork properly. Indeed, whenever possible, interested scholars should later revisit the site of the original fieldwork, and ideally even talk again to the very same people who had informed the original anthropologist.

When the first academic historians imitated anthropologists and took to the field to gather oral traditions or oral history, many of them did not realize at first that they could not just keep a record of their primary evidence to themselves, just as anthropologists had done for so long, and hope to be taken at their word. As Philip Curtin put it in 1968, these fieldworkers had to create archives as well as to use archives. He went on to propose standards for collecting and processing oral data, including advice about preservation of the primary evidence in a publicly accessible repository. ${ }^{2}$ His stance also inspired the requirement at the University of Wisconsin-Madison that a transcription and translation of a significant portion of the primary material used had to accompany doctoral dissertations based on oral tradition. Yet in spite of such pleas - or the practice of many oral history programs outside of African Studies that insisted on proper archivingmost Africanists continued neither to record their primary data for posterity (on microfilm at the time) nor to make them accessible to others. Hence in 1976 Beatrice Heintze had to plead the case for access to primary sources all over again. ${ }^{3}$ Since then some historians, such a Donald Wright, have scrupulously heeded the call for access, but unfortunately many others have not and that brings us to this note. ${ }^{4}$

Once again then let me repeat that recourse to scholarly authority is no longer sufficient to accept any argument based on inaccessible oral data. As

ied: a Field Evaluation of the Work of Marcel Griaule," Current Anthropology 32(1991), 139-67. It is evident from the discussion of his paper that some anthropologists still did not yet fully realize that human sociocultural activities can never be fully replicated because societies change all the time; see also van Beek, "Haunting Griaule: Experiences from the Restudy of the Dogon," HA 31(2004), 43-68.

2P.D. Curtin, "Field Techniques for Collecting and Processing Oral Data," JAH 9(1968), 367-85. A single proposed official repository in the United States for taped material at Indiana University did not fare very well. During my own research I created an archive of Rwandan oral data, and made it available some years later at several locations and later on microfilm at CAMP. A microfilm of various Kuba materials was also made and deposited there in the late 1970s.

3Beatrix Heintze, "Oral Tradition: Primary Source Only for the Collector?" HA 3(1976), 47-56.

${ }^{4}$ Donald Wright, Oral Traditions from the Gambia (Athens OH, 1979), two volumes designed to accompany and legitimize his monograph The Early History of Niumi (Athens $\mathrm{OH}, 1977$ ). In the allied field of folklore, many such publications of raw material exist and many scholars have archived all their data. 
long as the primary evidence on which it is based is not available for checking, no historical writing of whatever kind, is acceptable, and no scholar has to take such a piece of history writing into account. So if an author must create a repository in order to provide access to the primary data, she or he should do so. There is no longer any excuse to avoid doing so when data bases can be placed on appropriate websites, and those historians who work with oral traditions or oral history can make their corpus available in this or in similar ways. This rule will seem harsh only to those who are unaware of how easy it is to misrepresent such sources, even unwittingly, and how important such collections of oral historical material can be for the historiography of a period or a theme. The ongoing upheaval caused by the publication of the James Stuart Archive of oral traditions in the historiography of South Africa for the eighteenth and early nineteenth centuries is only the best known example of this.

More and more social and cultural anthropologists are also realizing that a similar rule should apply to monographs in their own field. Here too credibility has to depend on accessibility of the data base. Yet most anthropologists still refuse even to consider putting their raw materials from the field into the public domain, whether for fear of harming those who confided in them or that a nimbler colleague would "scoop" their data before they could publish their conclusions themselves. Both of these are legitimate concerns, yet they should not prevent anthropologists or other scholars (e.g., folklorists) from depositing their data in an appropriate repository. For these reasons anthropologists concerned with such matters have tended to bequeath their papers to public institutions only after their deaths. Thus the papers of a small number of well-known Africanist anthropologists have been preserved: for example, those of Leo Frobenius, R.S. Rattray, Michel Leiris, Marcel Griaule, Max Gluckman, and Isaac Schapera. Contrary to the unfortunate impression left by some polemics, access to their legacies has considerably increased the anthropological and historical value of their publications through a better understanding of the context in which they were composed. If it were not for the unexpected vagaries of life, one might be content to encourage other scholars simply to follow suit, even if this does delay the progress of knowledge somewhat. Yet, given these vagaries, it is safer and better to deposit the data as soon as possible, even if provision be made to make them accessible to the public only at a later date.

Field records of all sorts should be kept, not merely in order to permit their use with the publications that result from fieldwork, but also for an entirely 
different reason, a reason just as potent as the previous one, namely, that such records are irreplaceable sources in their own right to document social and cultural situations at the time of fieldwork. They often (not always!) contain a great deal of information elicited from colonial subjects, rather than rulers, and that information is frequently recorded verbatim, something that is very rare indeed in the major colonial archives. For example, the importance of the approximately 1400 pages of the papers of Fr. Peter Schumacher's on microfilm for the history of late precolonial and early colonial Rwanda can scarcely be exaggerated. His notes about the evolving identities of Hutu/Tutsi in colonial Rwanda are both irreplaceable and indispensable, not least because most of these are the recorded opinions of particular and well-identified Rwandans at the time..$^{5}$ In a generally similar way, the papers of Georges Smets (a historian) are so invaluable for the social history of colonial Burundi that the anthropologist AlbertTrouwborst felt it necessary to include a guide to them in his forthcoming monograph about the Rundi. ${ }^{6}$

Such examples of precious scholarly legacies are legion for almost every part of Africa, and readers will have no difficulty in identifying examples in their area of special concern. Let us therefore merely draw attention here to a class of data often neglected by historians: statistics and the raw materials (usually questionnaires) out of which they are built. Once the detailed sources for the Ashanti Social Survey, conducted by the well-known anthropologist Meyer Fortes in 1948 were found, apparently in a garage, they suddenly provided social historians of southern Ghana with a huge irreplaceable, and hitherto unimagined, data set about social history, and they have used it with great success. ${ }^{7}$ Similarly attention has been drawn to the cornucopia of information concerning social history contained in the raw data gathered for the censuses carried out in French West Africa. ${ }^{8}$

But why are such scholarly data so valuable for historical periods such as the late colonial period about which whole cordilleras of archival records await the explorers of public archives or those of large corporations? Scholarly information is particularly valuable because those mountains of archives consists of official information required for administrative, eco-

${ }^{5}$ Peter Schumacher, Ruanda. Micro-Bibliotheca Anthropos (Posieux, 1958). Schumacher was both anthropologist and missionary.

${ }^{6}$ Albert Trouwborst, Life on Burundi's Hills, in press, annex 2 The Smets files.

${ }^{7}$ Meyer Fortes, "The Ashanti Social Survey: a Preliminary Report," Rhodes-Livingstone Journal 6(1948), 27; T.C. McCaskie, Asante Identities: History and Modernity in an African Village (Edinburgh, 2000).

${ }^{8}$ Dennis Cordell, "Sample Surveys: Underexploited Sources for African Social History" in Sources and Methods in African History, eds. Toyin Falola and Christian Jennings (Rochester, 2003), 376-92. 
nomic, missionary, or educational purposes. They do not provide information about private activities, nor do they document routine social history, which is precisely the kind of data ethnographic fieldwork uncovers. Such data put flesh and bones, faces and dates, on colonial subjects in the abstract and turn pictures of "farmers in the primeval forest" into "John, Peter, and Paul of village X forced to plant cotton" or "wizard " into "prophet Moses introduces a new cult into village Y." It is easy to see why this kind of information is essential for any genuine understanding of how colonial conditions transformed the lives of an area's inhabitants-whatever the amount of other data available. Moreover, anthropological or oral data collected by academic historians are not official information, nor are they usually (but not always!) coerced in any way, nor are they usually dictated by policy concerns, although they often are by theoretical concerns. In sum, fieldwork data neatly crosscut all the other sets of sources and help to infuse new meaning into them. The same holds true for the different mix of sources generated during recent decades in Africa, as we witness a large decrease in the preservation of official archives and a huge increase in usually evanescent data generated by the media- but also a huge increase of fieldwork by different sorts of scholars in the field along with expatriate philanthropic agencies, and United Nations organisms.

The upshot is that everyone's raw records from the field should be preserved and made available as soon as concern for the safety of those who appear in them allows it. No one, historian or not, should imagine that raw data are not worth preserving simply because they cannot properly imagine on what themes future research will focus. Indeed, raw materials are especially useful for the evidence they unwittingly and accidentally preserve. Indeed, my own research papers recently taught me this lesson. They contain a large set of data recorded by local young men that is the only known evidence about the behavior, the ideas, and the expectations of the very first members of the modern social elite among the Kuba of the République Démocratique du Congo. Until recently I had completely missed this facet of that documentation.

\section{III}

During the last year I have been contacted three times for advice by bereaved families concerning the professional papers left by suddenly deceased scholars. In each case some of these files were important, irreplaceable, and unpublished. The frequency of these recent calls for advice should forcefully remind us of the passing of a generation of academic historians of Africa with vast experience in the field. One lesson of that fre- 
quency for former fieldworkers should be that the time to gather one's papers together and to organize them is now, and so is the time to worry about a permanent home for them. Perpetually postponing such decisions merely makes certain that they eventually will be made by persons who will probably be far less competent to do so than the scholar who accumulated the papers. Moreover, to arrange one's papers from the field for a repository is not complicated, the principle being (a) keep everything, absolutely everything, useful or useless, that comes out of the field or is related to it, and (b) put and keep everything together in labeled boxes. That everything also includes all audio and visual (video, film, photographs) materials, whatever their subject. That is the minimum that is needed. Of course, once one has done this, it is quite helpful to provide a detailed inventory of the whole.

Once everything is together, the next job is to find an archive to store the records and to make them available to others. In choosing an archive one should also consider whether all or most of the records can be safely digitized or microfilmed without loss of content or whether some or all of them need to be kept on paper or tape. Unfortunately Africanists will discover that it is not always easy to find a repository. In most of the former metropoles of African colonies provisions have been made at various institutional levels in states, cities, universities, or museums for archiving such scholarly legacies, but in other countries-and it seems especially in the United States-it can be far more difficult to find a safe home for such papers. Institutional archives here, including university archives, were created to house the administrative documents generated by the institution to which they belong, and they tend to refuse to store anything beyond the documents for which they are responsible. Usually they simply do not have the space to accept them. Hence, scholars in such circumstances should realize that it might take quite a bit of time to find an appropriate institution to deposit their records. But that should be all the more reason to start searching for such a repository as soon as possible.

It is not difficult for any reader to imagine how many scholars are involved in that first generation, and how much irreplaceable information would be lost if the records of the scholars who worked in the field in the second half of the twentieth century, and who are now about to retire, were not preserved. On the other hand, it is also not very difficult to estimate how much space would be needed to accommodate the rapidly accumulating documentation of all these scholars, nor does one need to be a genius to realize that the rare existing repositories in the United States will be submerged quite soon. There is an urgent need for the construction of new and appropriate archival facilities. But that can only happen if we scholars-and 
especially we historians - can raise the awareness of the dire need for such archives, as well as a sense of the urgency of the problem in professional archival and library circles and also within our universities, museums, African Studies programs, research institutes, and other professional associations.

Thus we are facing a paradox: on the one hand, the full records extant of oral traditions or oral history gathered in the field must be placed at least in an accessible repository in the interests of sound history, and a huge amount of precious information is often lost when the full records of all activities in the field are not housed there as well, yet, on the other hand, it can be quite difficult to find such a repository. The paradox flows of course from the circumstance that the societies and the countries for which this information is the most valuable do not have the means (and sometimes not even the security) to organize the necessary archives, while the societies and countries in which Africanist scholars flourish can create them but often are not interested enough to do so. Still that paradox must be overcome and we can only strive to achieve that goal: the records need to be kept and the archives need to be provided for them. 